\title{
Study on Strengthening of RC Beam Column Joint Using Hybrid FRP Composites
}

\author{
A. Arul Gnanapragasam"1, G. Chitra'2, S. Robert Ravi ${ }^{*}$ \\ ${ }^{1}$ Department of Civil Engineering, SSM Institute of Engineering and Technology, Dindigul, India \\ ${ }^{2}$ Department of Civil Engineering, Thiagarajar College of Engineering, Madurai, India \\ Email: *victorarul333@gmail.com
}

Received 11 May 2016; accepted 25 May 2016; published 4 August 2016

Copyright (C) 2016 by authors and Scientific Research Publishing Inc.

This work is licensed under the Creative Commons Attribution International License (CC BY).

http://creativecommons.org/licenses/by/4.0/

(c) (i) Open Access

\begin{abstract}
Beam-Column joints are critical zones in reinforced concrete structures which are most vulnerable to earthquake forces. Hence strengthening beam-column joint is vital to save the structure and its inhabitants in case of seismic forces. Numerous retrofitting works using fibre reinforced polymer (FRP) composites are being undertaken worldwide. This work aims to investigate the effectiveness of strengthening beam-column joints using natural and artificial fibres. In this study, basalt (natural fibres) as monolithic composite (BFRP) and as hybrid composite along with glass (artificial fibres) were used for strengthening of beam-column joints. Totally six specimens were prepared and tested under monotonic loading. Specimen details used were: two control specimen, two specimens for monolithic wrapping and remaining two specimens for hybrid wrapping. The test results were compared with control and rehabilitated specimens. The performance of the treated joints was studied using the following parameters: initial and ultimate cracking loads, energy absorption, deflection ductility and stiffness at ultimate. From the test results, it was found that the hybrid combination of Basalt and Glass FRPs were found to be more effective in the treatment of beam-column joints. The strong column weak beam concept was achieved by failure in beam portion which helped in preventing the catastrophic failure of the entire structure.
\end{abstract}

\section{Keywords}

FRP, Reinforced Concrete, Beam-Column Joints, Glass Fibre Reinforced Polymer, Basalt Fibre Reinforced Polymer

\section{Introduction and Literature Review}

Reinforced cement concrete (RCC) is a versatile material, popularly used worldwide in framed structures. How${ }^{*}$ Corresponding author. 
ever, its performance during the earthquakes has created lot of queries in the minds of researchers. Beam-column joints, being the lateral and vertical load resisting members in reinforced concrete structures are particularly vulnerable to failures during earthquakes [1]. It has also been found that exterior beam column joints are more vulnerable than interior joints [2]. This may be attributed to insufficient strength to withstand the lateral loads by the joints with the reason being poor detailing without due consideration to seismic provisions. This problem results in decreased ductility with diagonal shear developed in the joints leading to catastrophic failures. Inadequate transverse reinforcement in the joints and weak column — strong beam design are the main reasons observed for the joint shear failure during earthquakes [3]. Joints must be designed to allow for the dissipation of large amounts of energy in to the neighboring elements without significant loss of strength and ductility [4]. If the column is not wide enough or if the strength of concrete in the joint is low, there is insufficient grip of concrete on the steel bars. In such circumstances, the bar slips inside the joint region, and beams lose their capacity to carry load [5].

FRP materials have a number of favourable characteristics, namely: ease of installation; immunity to corrosion; extreme high strength; availability in convenient tailor made forms etc [6]. GFRP jacketing comes out to be an effective technique to regain the strength and stiffness of damaged joints [7]. Glass fibre (GFRP) jackets were found to be capable of increasing the shear resistance of the joints by enhancing its ductility. Using GFRP jacketing, the integrity of the concrete could be maintained by confinement, significantly improving the ductility and the load carrying capacity of the rehabilitated joint [8]. Web bonded FRP retrofitting at joints was found to result in $40 \%$ increase in the lateral load resisting capacity of RC frames [9]. The load carrying and energy absorption capacities were also found to increase for FRP treated specimens when compared to their control specimens. It was found through previous research studies that the failure was in the column portion of the joint for the control specimen which is to be avoided. It was found that the load carrying and the energy absorption capacities of retrofitted specimen were $60 \%$ and $30 \%$ - $60 \%$ more than that of control specimens [10].

\section{Experimental Investigation}

The objectives of this work are two fold:

- To study the effectiveness of strengthening external beam-column joints using the following treatment measures:

o BFRP as monolithic composites and

O BFRP along with GFRP as hybrid fibre composites

- To compare the performance of treated beam-column joints with that of the control specimens.

In this work, the RCC beam column external joints were designed as per IS: 456-2000. Six beam-column joint specimens were cast. The joints were subjected to monotonic loading — give details of load arrangement.

1) Two control and two specimens were wrapped by monolithic wrapping of BFRP,

2) Another two specimens were wrapped by hybrid wrapping of BFRP and GFRP.

3) Failed two control specimens were wrapped by hybrid wrapping of BFRP and GFRP.

\subsection{Details of the Specimen}

The reinforcement details of the beam-column joint used in the study are shown in Figure 1. The dimensions and reinforcement details of the beam and columns are as follows:

Beam

Cross section $=100 \mathrm{~mm} \times 100 \mathrm{~mm}$ with Length $=750 \mathrm{~mm}$.

Top reinforcements $=$ Two bars of $8 \mathrm{~mm}$ diameters.

Bottom reinforcements $=$ Two bars of $10 \mathrm{~mm}$ diameter and one bar of $8 \mathrm{~mm}$ diameter.

Stirrups $=6 \mathrm{~mm}$ diameter with the spacing of $75 \mathrm{~mm}$ centre to centre $(\mathrm{c} / \mathrm{c})$.

Column

Cross section $=100 \mathrm{~mm} \times 100 \mathrm{~mm}$ with Height $=1000 \mathrm{~mm}$.

Main reinforcement $=$ Four bars of $8 \mathrm{~mm}$ diameter.

Vertical ties $=6 \mathrm{~mm}$ diameter with a spacing of $75 \mathrm{~mm}$ centre to centre (c/c).

\subsection{Casting and Curing}

The concrete specimens were prepared with 53 grade Portland cement, locally available river sand as a fine ag- 


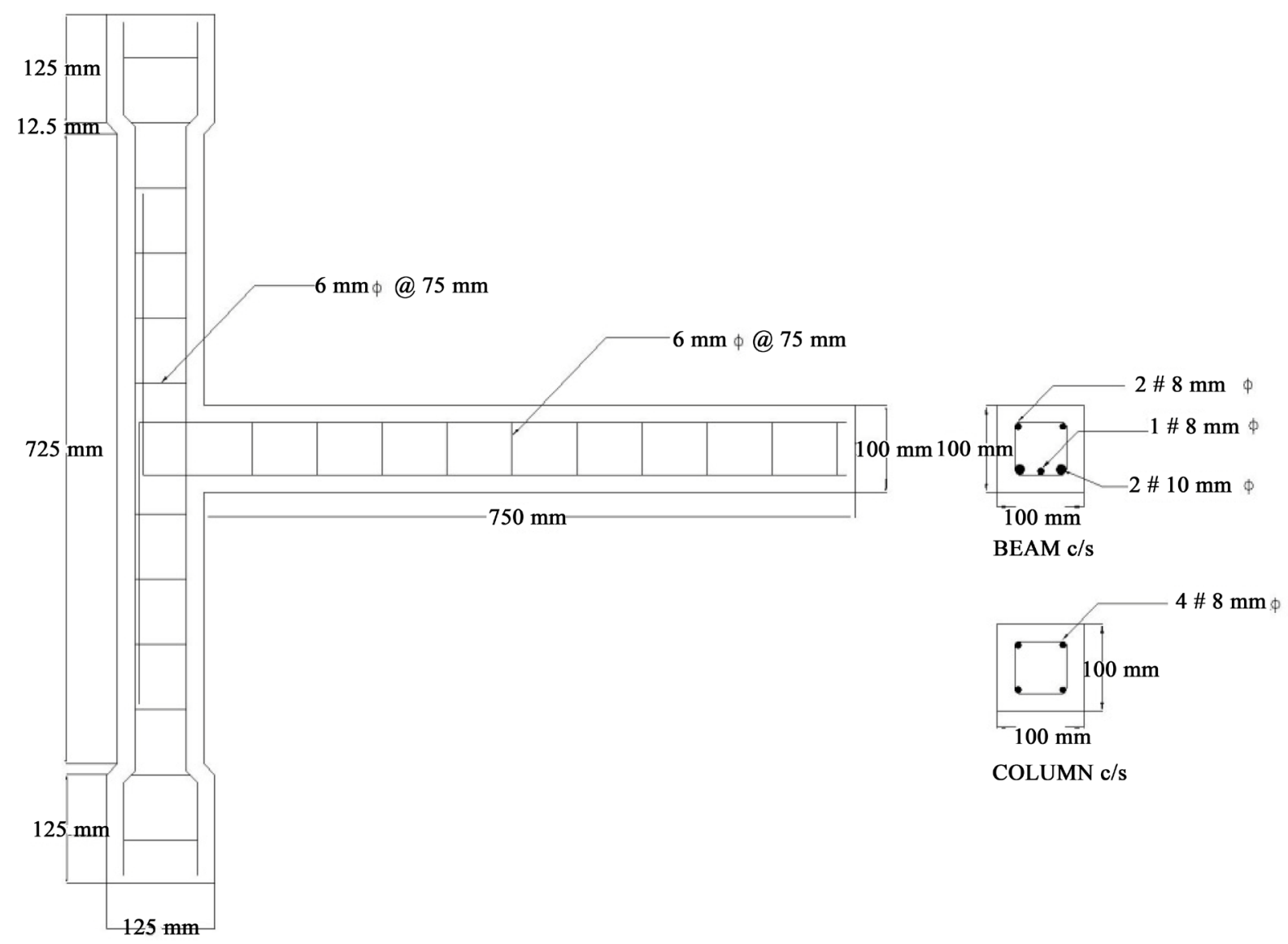

BEAM-COLUMN JOINT

Figure 1. Reinforcement details of beam-column joint.

gregate conforming to zone II as per IS 383-1970 and coarse aggregate passing $12.5 \mathrm{~mm}$ and retained in $10 \mathrm{~mm}$ sieve conforming to IS 383-1970. Potable water was used for casting and curing of all specimens. Concrete having characteristic compressive strength of $25 \mathrm{MPa}$ was used for casting the beam-column joints. The specific gravity of cement, fine aggregate and coarse aggregates were 3.1, 2.63 and 2.67. The mix proportion of concrete was 1:1.6:2.95 with water cement ratio of 0.55. After arranging the beam column joint mould, the inner surfaces were oiled well to enable easy removal of the specimen. The prepared reinforcement cage was placed inside the mould with proper cover of $15 \mathrm{~mm}$. Concrete was cast based on the mix proportion and placed in the formwork. The test specimens were de-moulded after 24 hours from the time of casting. The specimens were cured under water for 28 days before testing.

\section{Details of FRP Composites Used in the Study}

\subsection{Fibres}

The main functions of the fibres are to carry the load uniformly, provide stiffness, strength, thermal stability in the FRP composite. Basalt and Glass fibres used in the investigation are as shown in the Figure 2 and Figure 3. Their Properties are given in Table 1.

\subsection{Epoxy Resin}

The success of the strengthening technique critically depends on the performance of the resin used. In this work epoxy resin was used. These epoxies are generally a two part system, a resin and hardener. The resin and hardener used in this study were Araldite GY 257 and Hardener HY 840 respectively. The properties of epoxy resin and hardener are summarized in Table 2. 


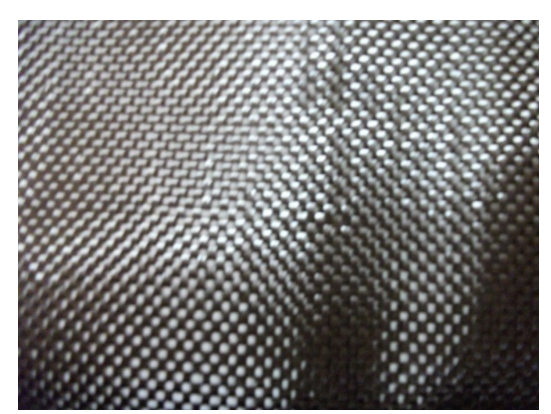

Figure 2. Basalt fibre.

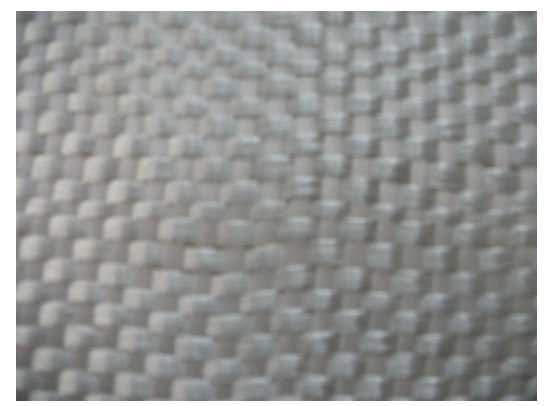

Figure 3. Glass fibre.

Table 1. Properties of fibres used (as given by the manufacturer).

\begin{tabular}{cccc}
\hline S. No & Properties & BFRP & GFRP (E-Glass) \\
\hline 1. & Density $\left(\mathrm{g} / \mathrm{cm}^{3}\right)$ & 2.65 & 2.5 \\
2. & Elongation at break (\%) & 3.3 & 2.5 \\
3. & Tensile strength (MPa) & 4200 & 3400 \\
4. & Youngs Modulus (GPa) & 105 & 70 \\
\hline
\end{tabular}

Table 2. Properties of epoxy resin and hardener used (as given by the manufacturer).

\begin{tabular}{cccc}
\hline S.No & Properties & Araldite GY 257 & Hardener HY 840 \\
\hline 1. & Density at $25^{\circ} \mathrm{C} \mathrm{g} / \mathrm{cm}^{3}$ & 1.15 & 0.98 \\
2. & Specific gravity & 1.8 & 2 \\
3. & Flexural strength $\mathrm{kg} / \mathrm{cm}^{3}$ & $450-550$ & $300-400$ \\
\hline
\end{tabular}

\section{Experimental Test Set up}

The testing arrangement of beam-column joint is shown in Figure 4. The beam-column joints were tested with a constant axial load on the column and a static load applied at the beam tip. The joint was tested by giving an initial axial restraining force to the column of $20 \mathrm{kN}$ using hydraulic jack. The designed load carrying capacity of the column was $64 \mathrm{kN}$.

The static load tests were conducted on the control and retrofitted reinforced concrete joint specimens. If the axial load of the column exceeded fifty percentage of its capacity, the effect of axial load will be more on the joint. So as to maintain the seismic load behavior in the beam column joint, the axial load was restricted and it is decided to apply the load up to fifty percentage of the load carrying capacity of the column only.

Hydraulic jacks were used for applying the axial force and it was monitored using the load cell and data acquisition system.

Totally six specimens were prepared for testing. Two control specimens were tested up to its ultimate failure load. Remaining four specimens were tested by applying seventy percentage of their ultimate load. After testing the failed control beam-column joint specimens namely: BCJC1and BCJC2, were rehabilitated and re-designated as 
specimens BCJR1and BCJR2 respectively. The crack portions were filled with cement paste after cleaning the surfaces. In damaged portion the same grade of concrete was used and compacted well. The specimens were placed in water for 28 days curing. Specimens BCJB1 \& BCJB2 were wrapped using basalt fibre monolithically after giving 70 percentage of ultimate load. Remaining two specimens BCJBG1, BCJBG2 were wrapped using hybrid FRP wrapping methods.

\subsection{Bonding Procedure}

Before wrapping the fibre sheets, the edges and surfaces of the specimens were ground by mechanical means. The concrete surface was slightly chiseled off with pointed chisel to remove material for enhancing good bonding and cleaned with water to remove all dirt and debris. Once the surface had been prepared, the epoxy resin was prepared. Mixing was carried out with Araldite GY 257 and Hardener HY 840 in the proportion of 1:0.5. The epoxy coating was applied over the specimen and the first layer of fibre sheets was placed over the surface of beam column joint. A hand roller was used to roll over the surface gently to remove the voids from the surface. After 7 days of curing, the epoxy coating was applied over the sheet and then, the second layer sheet was placed. Figure 5 shows the typical views of specimens wrapped with monolithic and hybrid FRP composites.

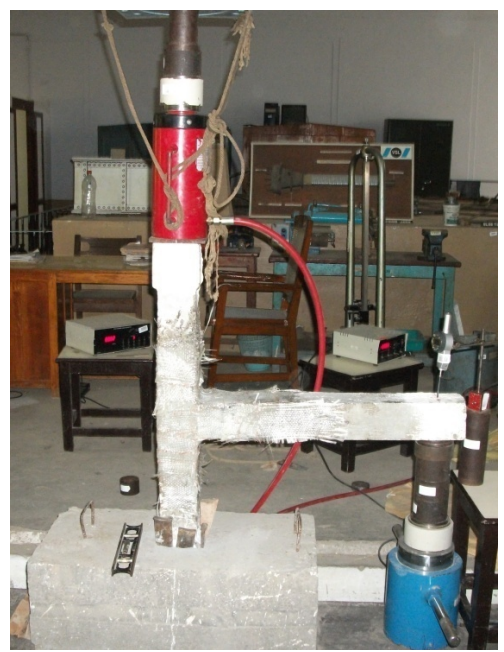

Figure 4. Testing arrangement of the beam-column joint.

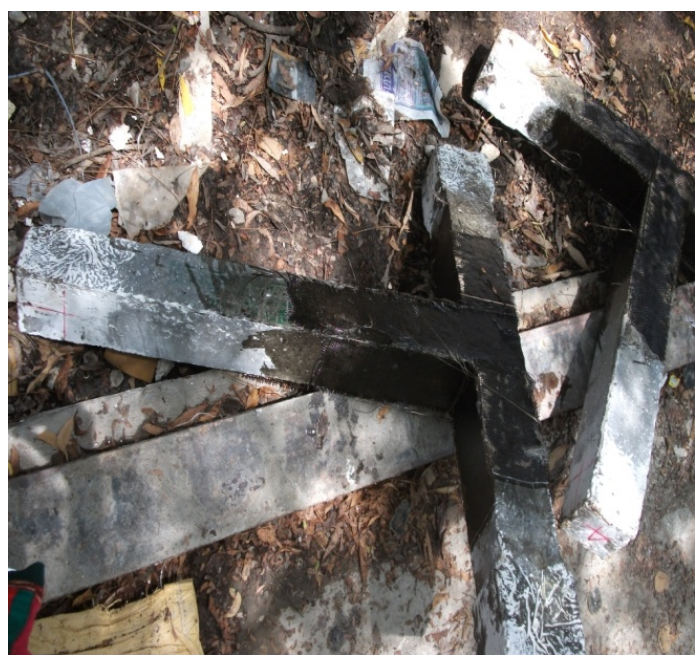

(a)

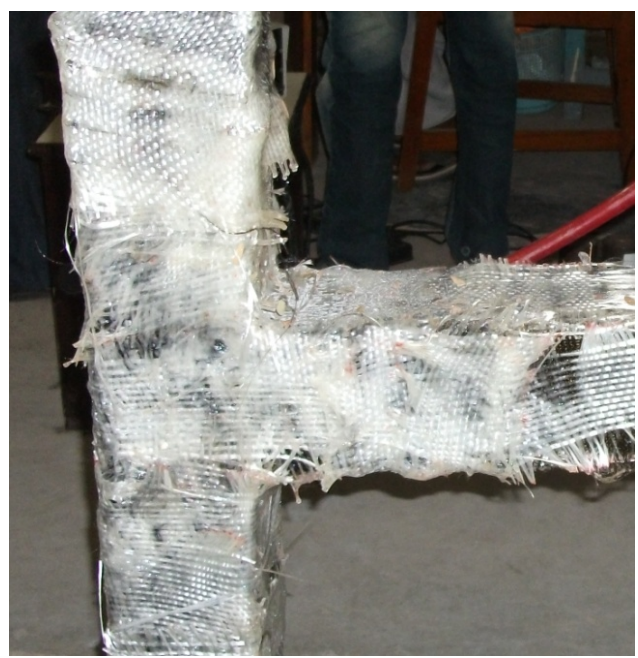

(b)

Figure 5. Typical views of retrofitted specimens. (a) Monolithic wrapping by BFRP sheet; (b) Hybrid wrapping by BFRP \& GFRP sheets. 


\subsection{Description of Test Details}

Two control specimens BCJC1 and BCJC2 were tested to failure. Their ultimate load carrying capacity was found to be $10 \mathrm{kN}$. Remaining four specimens were tested by applying the 70 percentage of the ultimate load carrying capacity of the control specimen. After FRP, wrapping the specimens was tested up to their ultimate load. The ultimate load carrying capacity of each specimen found through the test is given in the Table 3. Figure 6(a) and Figure 6(b) shows the typical views of failed rehabilitated specimens.

\section{Results and Discussion}

From the light of the experimental investigation, the behavior of beam-column joints found for control and strengthened beams are discussed in the following paragraph.

\subsection{Initial and Ultimate Cracking Load}

The initial cracking and ultimate loads of all the rehabilitated specimens were found to be more than their control specimens. This could be attributed to the percolation of epoxy resin used for bonding of fibres through the cracks in the joints, thereby enhancing its strength characteristics. The values initial and ultimate cracking loads are shown in Table 3 and Figure 7.

\subsection{Load Displacement Curve}

Figure 8 shows the load-displacement curves of control, monolithic basalt FRP, hybrid of basalt and glass FRP

Table 3. Initial and ultimate cracking loads for various specimen.

\begin{tabular}{ccc}
\hline Details of Specimen & Initial Cracking Load (kN) & Ultimate Load (kN) \\
BCJC1 (control) & 4 & 10 \\
BCJC2 (control) & 3.5 & 10 \\
BCJB1 (Basalt) & 8.5 & 12 \\
BCJB 2 (Basalt) & 9 & 11 \\
BCJBG1(Hybrid) & 8 & 16 \\
BCJBG2(Hybrid) & 6 & 14 \\
BCJR1 (Rehabilitated) & 5 & 12 \\
BCJR2 (Rehabilitated) & & 13 \\
\hline
\end{tabular}

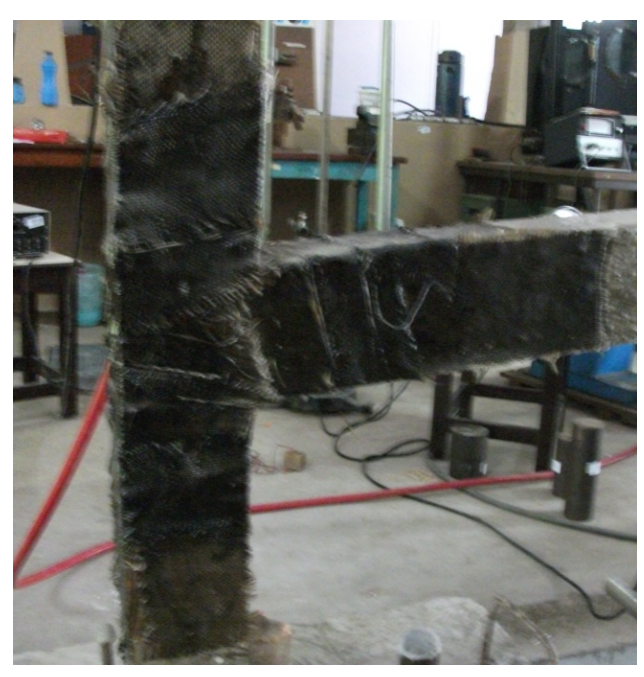

(a)

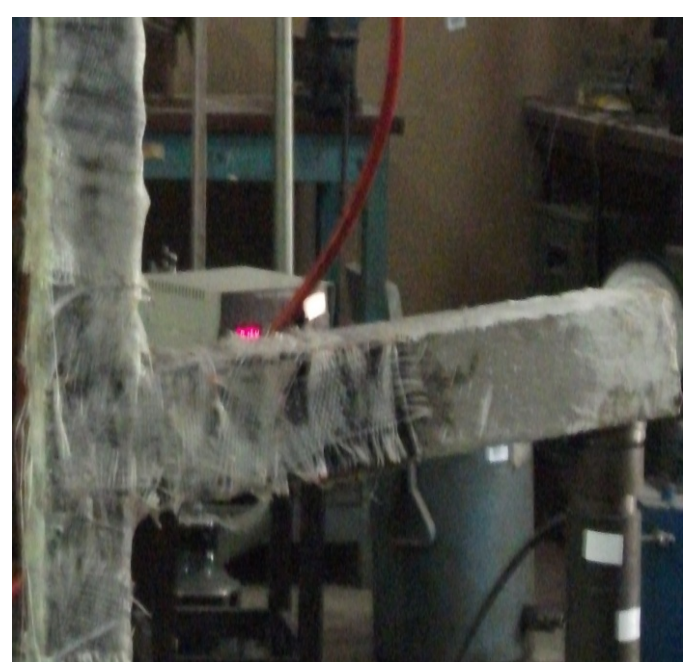

(b)

Figure 6. (a) Failure of monolithic BFRP treated joints; (b) Failure of hybrid BFRP BFRP treated joints. 


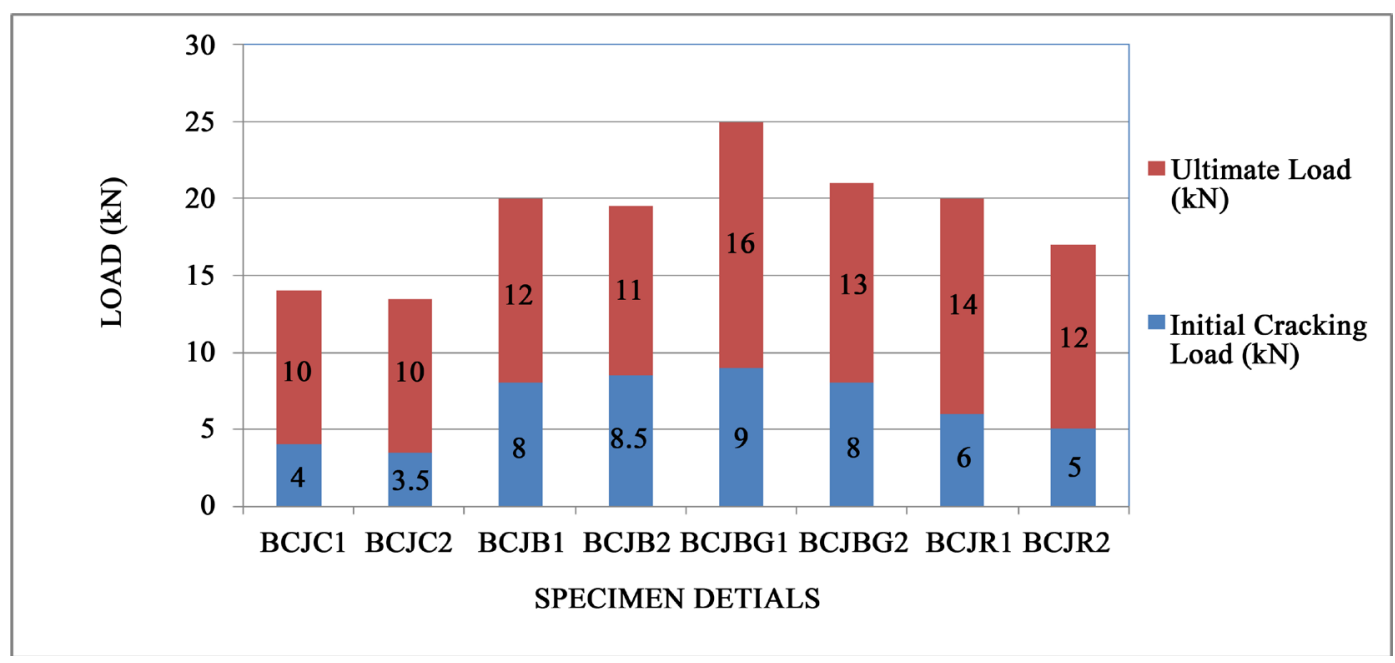

Figure 7. Initial and ultimate cracking loads for various specimen.

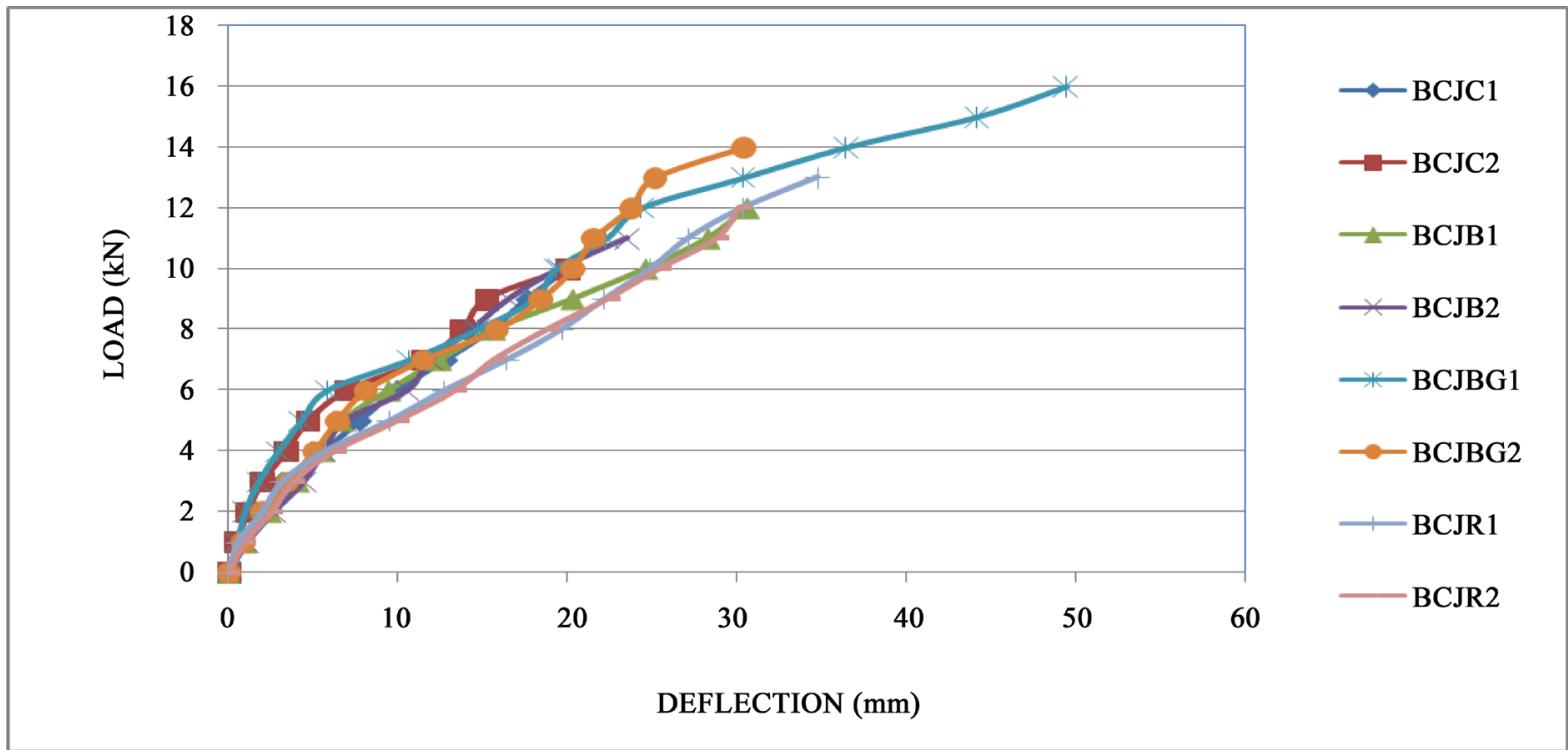

Figure 8. Load displacement curves.

and rehabilitated control hybrid of basalt and glass FRP specimens. Using these curves the yield load, ultimate load, ultimate displacements, ductility and stiffness at ultimate load were obtained for all the specimens.

\subsection{Energy Absorption}

Energy absorption can be calculated as the area under the beam tip load vs its displacement curve. The energy absorption values of control specimens and those rehabilitated specimens are shown in Table 4. From the Figure 9 it is significant that the rehabilitated specimens show increase in energy absorption.

\subsection{Deflection Ductility and Stiffness}

Deflection ductility is defined as the ratio of deformation at ultimate load to that at yield load. Stiffness at ultimate load is defined as the ultimate load to the ultimate deformation. The ductility and stiffness values of control specimens and rehabilitated specimens are given in Table 5. All the rehabilitated specimens were found to show more ductility than control specimens. But the stiffness of control specimens were found to be more than the treated ones. 


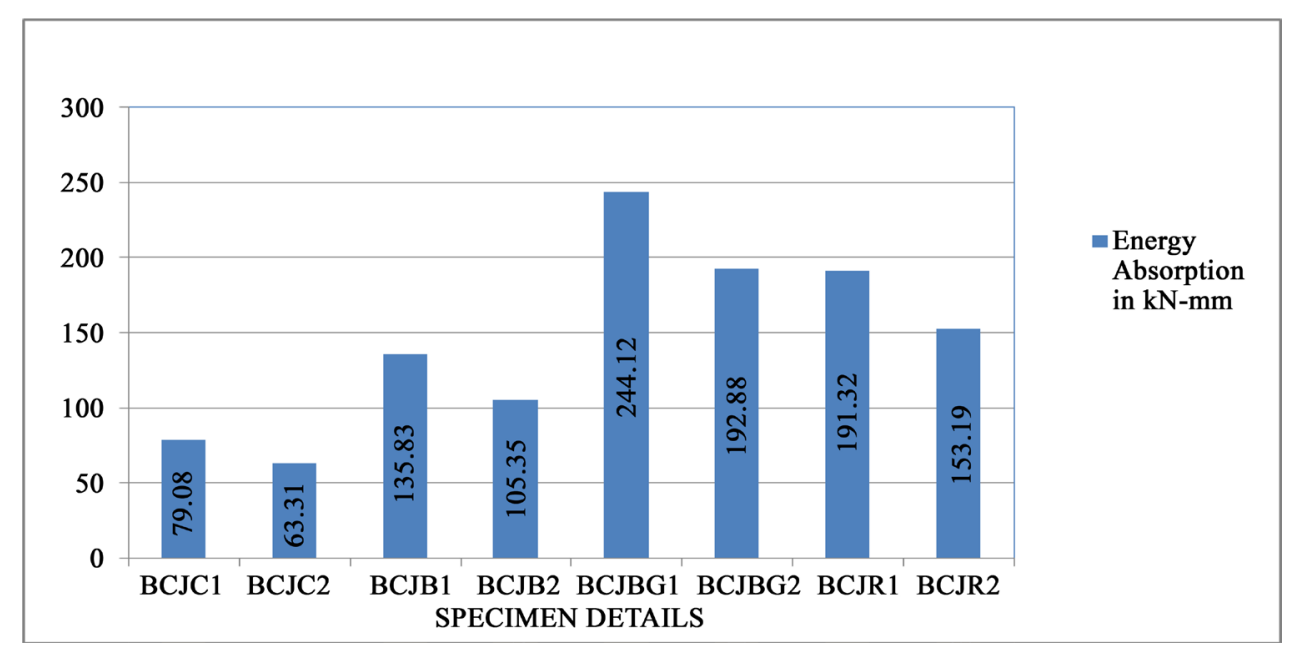

Figure 9. Energy absorption for various specimens.

Table 4. Energy absorption for various specimens.

\begin{tabular}{cc}
\hline Details of Specimen & Energy Absorption in (kN-mm) \\
\hline BCJC1 (control) & 79.08 \\
BCJC2 (control) & 63.31 \\
BCJB1 (Basalt) & 135.83 \\
BCJB2 (Basalt) & 105.35 \\
BCJBG1 (Hybrid) & 244.12 \\
BCJBG2 (Hybrid) & 192.88 \\
BCJR1 (Rehabilitated) & 191.32 \\
BCJR2 (Rehabilitated) & 153.19 \\
\hline
\end{tabular}

Table 5. Deflection ductility ratios and stiffness values of various specimens.

\begin{tabular}{ccc}
\hline Details of Specimen & Deflection Ductility ratios & Stiffness $(\mathbf{k N} / \mathbf{m m})$ \\
\hline BCJC1 (control) & 3.67 & 0.49 \\
BCJC2 (control) & 3.58 & 0.48 \\
BCJB1 (Basalt) & 5.26 & 0.39 \\
BCJB2 (Basalt) & 4.2 & 0.46 \\
BCJBG1 (Hybrid) & 8.5 & 0.32 \\
BCJBG2 (Hybrid) & 6.1 & 0.37 \\
BCJR1 (Rehabilitated) & 5 & 0.45 \\
BCJR2 (Rehabilitated) & 4.82 & 0.4 \\
\hline
\end{tabular}

\section{Comparison of Specimens}

The effectiveness of using FRP composites for treatment of beam-column joints was studied experimentally by comparing the performance of rehabilitated specimens mutually and with that of their control specimens. The parameters taken for the comparison were initial cracking load, ultimate load, energy absorption, deflection ductility and stiffness at ultimate loads. The details are discussed in the following paragraphs.

\subsection{Comparison of Initial Cracking Load of Specimens}

When compared with control specimens, all rehabilitated specimens showed better performance with respect to initial cracking load. Table 6 shows the comparison of initial cracking loads for various specimens. As can be 
seen hybrid FRP treated specimen showed the best performance of all the other specimens.

\subsection{Comparison of Ultimate Load Carrying Capacities of Specimens}

When compared with control specimen, all rehabilitated specimen showed better performance in ultimate load carrying capacities. Table 7 shows the comparison of ultimate load of various specimens. Similar to the above parameter here also hybrid FRP treated specimens showed the best performance.

\subsection{Comparison of Energy Absorption Values of Specimens}

A comparison of energy absorption of the specimens is as shown in Table 8. When compared with control specimen, all rehabilitated specimens showed better performance. Hybrid FRP rehabilitated specimens showed the maximum value compared to all the other specimens.

\subsection{Comparison for Deflection Ductility}

The rehabilitated specimens with hybrid fibres were found to produce an increased deflection ductility of $131.6 \%$ with that of control specimens. This shows that all the treated specimens are ductile than the control ones. Table 9 shows the comparison of Deflection ductility values of various specimens.

Table 6. Comparison of initial cracking loads for various specimens.

\begin{tabular}{cccc}
\hline Details of Specimen & Initial cracking Load (kN) & $\begin{array}{c}\text { \% Increase/Decrease with } \\
\text { respect to control specimen }\end{array}$ & $\begin{array}{c}\text { \% Increase/Decrease with } \\
\text { respect to Hybrid specimen }\end{array}$ \\
\hline BCJC (control) & 4 & +100 & -55.56 \\
BCJB (Basalt) & 8 & +125 & -11.11 \\
BCJBG (Hybrid) & 9 & +50 & - \\
BCJR (Rehabilitated) & 6 & -33.33 \\
\hline
\end{tabular}

Table 7. Comparison of ultimate load values for various specimens.

\begin{tabular}{cccc}
\hline Details of Specimen & $\begin{array}{c}\text { Ultimate Load } \\
(\mathbf{k N})\end{array}$ & $\begin{array}{c}\text { \% Increase/Decrease with } \\
\text { respect to control specimen }\end{array}$ & $\begin{array}{c}\text { \% Increase/Decrease with } \\
\text { respect to Hybrid specimen }\end{array}$ \\
\hline BCJC (control) & 10 & - & -60 \\
BCJB (Basalt) & 12 & +20 & -25 \\
BCJBG (Hybrid) & 16 & +30 & - \\
BCJR (Rehabilitated) & 13 & -18.75 \\
\hline
\end{tabular}

Table 8. Comparison of energy absorption values of specimens.

\begin{tabular}{cccc}
\hline Details of Specimen & Energy Absorption (kN-mm) & $\begin{array}{c}\text { \% Increase/Decrease with } \\
\text { respect to control specimen }\end{array}$ & $\begin{array}{c}\text { \% Increase/Decrease with } \\
\text { respect to Hybrid specimen }\end{array}$ \\
\hline BCJC (control) & 79.08 & - & -67.60 \\
BCJB (Basalt) & 135.83 & +71.76 & -44.35 \\
BCJBG (Hybrid) & 244.12 & +141.93 & - \\
BCJR (Rehabilitated) & 191.32 & -21.62 \\
\hline
\end{tabular}

Table 9. Comparison of deflection ductility values of various specimen.

\begin{tabular}{cccc}
\hline Details of Specimen & Deflection ductility ratios & $\begin{array}{c}\text { \% Increase/Decrease with } \\
\text { respect to control specimen }\end{array}$ & $\begin{array}{c}\text { \% Increase/Decrease with } \\
\text { respect to Hybrid specimen }\end{array}$ \\
\hline BCJC (control) & 3.67 & - & -56.82 \\
BCJB (Basalt) & 5.26 & +43.32 & -38.11 \\
BCJBG (Hybrid) & 8.5 & +131.6 & - \\
BCJR (Rehabilitated) & 4.82 & -43.29 \\
\hline
\end{tabular}


Table 10. Comparison of Stiffness values of various specimen.

\begin{tabular}{cccc}
\hline Details of Specimen & Stiffness & $\begin{array}{c}\text { \% Increase/Decrease with } \\
\text { respect to control specimen }\end{array}$ & $\begin{array}{c}\text { \% Increase/Decrease with } \\
\text { respect to Hybrid specimen }\end{array}$ \\
\hline BCJC (control) & 0.49 & - & +32.43 \\
BCJB (Basalt) & 0.46 & -6.12 & +24.32 \\
BCJBG(Hybrid) & 0.37 & -24.48 & - \\
BCJR (Rehabilitated) & 0.45 & -8.16 & +21.62 \\
\hline
\end{tabular}

\subsection{Comparison for Stiffness}

A comparison of stiffness values of specimens are as shown in the Table 10. The rehabilitated specimens with hybrid fibres were found to produce a decrease in stiffness of $24.48 \%$ with that of control specimen. The control specimens were found to produce an increase in stiffness of $32.43 \%$ with that of the hybrid specimens.

\section{Conclusions}

From the experimental investigation of beam-column joints of control and retrofitted (Glass, Basalt and hybrid) specimens, the following conclusions were drawn.

1) The initial cracking load was found to be increased by $125 \%$ for RCC beam column joint specimen rehabilitated with hybrid of BFRP sheet and GFRP sheet, 100\% for those rehabilitated using BFRP sheet when compared with control specimens.

2) The ultimate load was found to be increased by $60 \%$ for RCC beam column joint specimen rehabilitated with hybrid of BFRP sheet and GFRP sheet and $20 \%$ for those rehabilitated using BFRP sheet when compared with control specimen.

3) The Energy absorption value was found to be increased by $208.70 \%$ for RCC beam column joint specimen rehabilitated with hybrid of BFRP sheet and GFRP sheet and 71.76\% for those rehabilitated using BFRP sheet when compared with control specimens.

4) The rehabilitated specimens with hybrid fibres were found to produce an increased in deflection ductility of 131.6\% for RCC beam column joint specimen rehabilitated with hybrid of BFRP sheet and GFRP sheet and 43.32\% for those rehabilitated using BFRP sheet when compared with control specimens.

5) The rehabilitated specimens with hybrid fibres were found to produce a decreased in stiffness of $24.48 \%$ with that of control specimens. The control specimens were found to produce an increase in stiffness with that of the rehabilitated specimens.

6) In the control specimen, the failure is in the column but in the retrofitted specimen the failure is in the beam. From this, the strong column weak beam concept is achieved and this helps in preventing the failure of the entire structure.

The above results show that hybrid combination of BFRP and GFRP was found to be more effective in the treatment of beam column joint.

\section{References}

[1] Robert Ravi, S. and Prince Arulraj, G. (2010) Experimental Investigation on the Behavior of R.C.C. Beam-Column Joints Retrofitted with GFRP-AFRP Hybrid Wrapping Subjected to Load Reversal. International Journal of Mechanics and Solids, 5, 61-69.

[2] El-Amoury, T. and Ghobarah, A. (2002) Seismic Rehabilitation of Beam-Column Joint Using GFRP Sheets. Engineering Structures, 24, 1397-1407. http://dx.doi.org/10.1016/S0141-0296(02)00081-0

[3] Tsonos, A.G. (2008) Effectiveness of CFRP-Jackets and RC-Jackets in Post-Earthquake and Pre-Earthquake Retrofitting of Beam-Column Sub Assemblages. Engineering Structures, 30, 777-793. http://dx.doi.org/10.1016/j.engstruct.2007.05.008

[4] Mahini, S.S. and Ronagh, H.R. (2010) Strength and Ductility of FRP Web-Bonded RC Beams for the Assessment of Retrofitted Beam-Column Joints of Retrofitted Beam-Column Joints. Composite Structures, 92, 1325-1332. http://dx.doi.org/10.1016/j.compstruct.2009.09.006

[5] Senthil Kumar, E. and Thirugnanam, G.S. (2010) Experimental Study on Behavior of Retrofitted with FRP Wrapped RC Beam Column Exterior Joints Subjected to Cyclic Loading. International Journal of Civil and Structural Engi- 
neering, 135-149.

[6] Balasubramanian, K., Lakshmanan, N., Antony Jeyasehar, C., Krishnamoorthy, T.S. and Bharatkumar, B.H. (2011) Experimental Investigations on FRP Retrofitted RC Beam-Column Specimens. Journal of Structural Engineering, 38, 405-416.

[7] Agarwal, P., Gupta, A. and Angadi, R.G. (2014) Effect of FRP Wrapping on Axial Behavior of Concrete and Cyclic Behaviour of External RC Beam Column Joints. KSCE Journal of Civil Engineering, 18, 566-573. http://dx.doi.org/10.1007/s12205-014-0259-y

[8] Ahmed Ghobarah, A.S. (2002) Shear Strengthening of Beam-Column Joints. Engineering Structures, 24, 881-888. http://dx.doi.org/10.1016/S0141-0296(02)00026-3

[9] Niroomandi, A., Maheri, A., Maheri, M.R. and Mahini, S.S. (2010) Seismic Performance of Ordinary RC Frames Retrofitted at Joints by FRP Sheets. Engineering Structures, 32, 2326-2336. http://dx.doi.org/10.1016/i.engstruct.2010.04.008

[10] Vijayalakshmi, N., Kalaivani, M., Murugesan, A. and Thirugnanam, G.S. (2010) Experimental Investigation of RC Beam Column Joint Strengthening by FRP Wrapping. International Journal of Civil and Structural Engineering, 1, 3549.

\section{Submit or recommend next manuscript to SCIRP and we will provide best service for you:}

Accepting pre-submission inquiries through Email, Facebook, LinkedIn, Twitter, etc.

A wide selection of journals (inclusive of 9 subjects, more than 200 journals)

Providing 24-hour high-quality service

User-friendly online submission system

Fair and swift peer-review system

Efficient typesetting and proofreading procedure

Display of the result of downloads and visits, as well as the number of cited articles

Maximum dissemination of your research work

Submit your manuscript at: http://papersubmission.scirp.org/ 